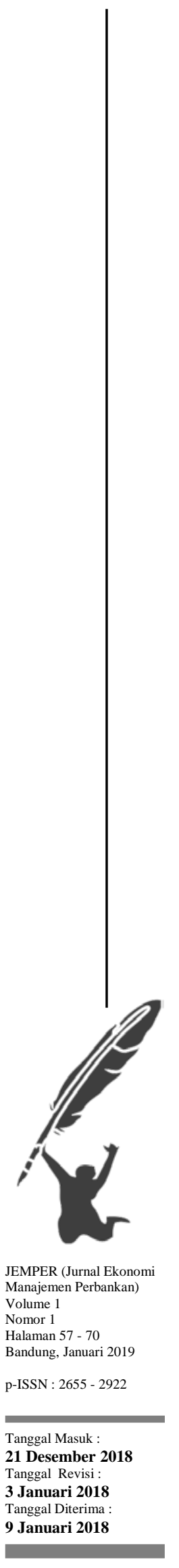

JEMPER(Jurnal Ekonomi Manajemen Perbankan)

http://jurnal.usbypkp.ac.id/index.php/jemper

\title{
PENGARUH INSTITUTIONAL OWNERSHIP, PROFITABILITY \\ DAN LEVERAGE TERHADAP KONDISI FINANCIAL DISTRESS \\ PADA PERUSAHAAN MANUFAKTUR YANG LISTED DI BEI
}

\author{
Ferdian ${ }^{1}$ \\ Universitas Sangga Buana YPKP Bandung \\ ferdian@gmail.com
}

\begin{abstract}
This research was conducted to examine the effect of the variable $\left(X_{-} 1\right)$ Institutional Ownership with measuring instruments using the KINS dimension, (X_2) Profitability with measuring instruments using the dimensions of return on assets and $\left(X \_3\right)$ Leverage with measuring instruments using the dimensions of debt to total assets, against $(Y)$ financial distress with measuring instruments using the dimension of earnings per share in manufacturing sector companies listed on the IDX for the 2011-2015 period. The sampling technique used stratified random sampling, a sample of 30 companies from 151 companies that have complete criteria. The analysis technique used is multiple regression random effect method and hypothesis testing, the analysis shows that the Institutional Ownership variable partially has a significant and positive effect.

at the level of significance of 5\%, but partially there is no significant and positive effect on Profitability, while on the Leverage variable partially there is a significant and negative effect on Financial Distress. Simultaneously, Institutional Ownership, Profitability and Leverage are not proven to have a significant effect on financial distress in manufacturing sector companies listed on the IDX at a level of significance greater than 5\%. The predictive ability of the three variables on Financial Distress is $3.37 \%$, while the remaining $96.3 \%$ (100\% - 3.37\%) is explained by other variables that are not researched or not included in this research model.
\end{abstract}

Keywords : Institutional Ownership, Profitability, Leverage, dan Earning Per Share

\begin{abstract}
Abstrak
Penelitian ini dilakukan untuk menguji pengaruh variabel (X_1) Institutional Ownership dengan alat ukur menggunakan dimensi KINS, (X_2) Profitability dengan alat ukur menggunakan dimensi return on asset dan (X_3) Leverage dengan alat ukur menggunakan dimensi debt to total asset, terhadap ( $\mathrm{Y}$ ) financial distress dengan alat ukur menggunakan dimensi earning per share pada perusahaan sektor manufaktur yang listed di BEI periode 2011-2015. Teknik pengambilan sampel menggunakan stratified random sampling, sampel sebanyak 30 perusahaan dari 151 perusahaan yang mempunyai kelengkapan kriteria. Teknik analisis yang digunakan adalah regresi berganda random effect metode dan uji hipotesis, analisis menunjukkan bahwa variabel Institutional Ownership, secara parsial terdapat pengaruh yang signifikan dan positif pada level of significance dari 5\%, namun pada Profitability secara parsial tidak terdapat pengaruh yang signifikan dan positif sedangkan pada variabel Leverage secara parsial terdapat pengaruh yang signifikan dan negatif terhadap Financial Distress. Secara simultan Institutional Ownership, Profitability dan Leverage tidak terbukti berpengaruh secara signifikan terhadap financial distress pada perusahaan sektor manufaktur yang listed di BEI pada level of significance lebih besar dari 5\%. Kemampuan prediksi dari ketiga variabel tersebut terhadap Financial Distress 3,37\%, sedangkan sisanya sebesar 96,3\% (100\%- 3,37\%) dijelaskan oleh variabel lain yang tidak diteliti atau tidak dimasukkan dalam model penelitian ini.
\end{abstract}

Kata kunci : Kepemilikan Institusional, Profitabilitas, Leverage, dan Pendapatan Per Lembar Saham 


\section{PENDAHULUAN}

Pertumbuhan perekonomian suatu negara dapat dilihat dari tingkat produksi barang dan jasa yang dapat dihasilkan negara tersebut dalam satu periode tertentu, namun pertumbuhan perekonomian negara berkembang seperti Indonesia sangatlah bergantung pada masalah modal dan investasi, hal inilah yang seringkali menjadi hambatan bagi Indonesia untuk meningkatkan pertumbuhan ekonominya. Untuk menyikapi masalah sulitnya menyerap modal dari pihak investor agar mau berinvestasi diindonesia salah satunya dapat dilakukan dengan memperbaiki kinerja keuangan perusahaan-perusahaan diindonesia. Di indonesia banyak sekali perusahaan yang terkena dampak dari krisis ekonomi global, namun yang paling mencolok penurunannya adalah perusahaan-perusahaan yang bergerak disektor manufaktur, kinerja perusahaan manufaktur nasional mengalami perlambatan pada kuartal pertama 2017 dengan mencatatkan indeks pembelian manajer (PMI), sebesar 51,5 sedangkan pada kuartal sebelumnya 51,9 (Data Kemenperin). Hal ini sangat disayangkan sekali karena perusahaan manufaktur adalah perusahaan yang memiliki jumlah yang dominan untuk perusahaan yang listed di BEI, yang secara tidak langsung baik atau buruknya kinerja perusahaan manufaktur akan sangat berpengaruh terhadap pertumbuhan ekonomi Indonesia. Kendati demikian prospek perusahaan manufaktur diindonesia masih sangat menjanjikan dengan catatan perusahan manufaktur diindonesia dapat mengatasi faktor-faktor yang menghambat kinerja perusahaan, faktor tersebut diantaranya adalah kurangnya ketersediaan modal dalam bentuk investasi serta buruknya kinerja keuangan pada perusahaan tersebut. Kinerja keuangan pada perusahaan sangatlah penting karena kinerja keuangan suatu perusahaan bisa mencerminkan seluruh perusahaan tersebut. Perusahaan yang kinerja keuanganya baik tentu saja akan menarik minat investor untuk berinvestasi pada perusahaan tersebut, sedangkan bila kinerja keuangan suatu perusahaan tidak baik tentu investor akan enggan untuk berinvestasi pada perusahaan tersebut, hal ini tentu saja akan berpengaruh pada nilai saham perusahaan tersebut. Dengan adanya kecukupan modal diharapkan perusahaan manufaktur akan mampu bertransformasi kearah yang lebih baik, sehingga akan meningkatkan daya saing dengan perusahaan lainnya, daya saing suatu perusahaan sangatlah penting karena perusahaan yang sudah tidak mampu lagi untuk bersaing tentu akan mengalami kerugian yang akan menyebabkan kondisi financial distress yang apabila dibiarkan berlarut-larut maka akan mengakibatkan kebangkrutan pada perusahaan tersebut. Dengan kata lain kinerja keuangan suatu perusahaan bisa menjadi gambaran kondisi keuangan suatu perusahaan pada periode tertentu. Informasi laporan keuangan yang akurat tentu sangat penting bagi pihak eksternal sebagai acuan dalam mengevaluasi kinerja perusahaan tersebut, akan tetapi bila terjadi penyalahgunaan informasi keuangan tentu akan mengakibatkan tidak sinkronnya informasi yang didapatkan, hal inilah yang dapat mengakibatkan kegagalan investasi dimasa yang akan datang.

Selain masalah dari buruknya penerapan corporate governance diatas, beberapa perusahaan manufaktur juga mengalami penurunan produksi dikarenakan permintaan yang juga menurun sehingga hal tersebut juga mempengaruhi dalam kuantitas penjualannya. Peristiwa menurunanya penjualan ini juga membuat beberapa perusahaan mengalami earning per share (EPS) yang cenderung negatif sehingga perusahaan tersebut bisa kesulitan dalam menjaga profitabilitasnya. Jika hal ini dibiarkan terus menerus bukan tidak mungkin akan dapat memicu terjadinya financial distress dan pada akhirnya akan berujung pada kebangkrutan perusahaan tersebut. Untuk dapat mendeteksi kemungkinan terjadinya financial distress disuatu perusahaan dapat digunakan analisis rasio keuangan. Secara umum rasio-rasio seperti profitability, likuiditas, dan leverage dapat dijadikan sebagai indikator yang paling signifikan dalam memprediksi financial distress maupun kebangkrutan, adanya ancaman terjadinya financial distress membuat perusahaan harus memiliki strategi yang 
tepat untuk mengantisipasi kondisi-kondisi yang menyebabkan masalah keuangan yang mungkin terjadi. Ketidaksiapan perusahaan dalam memprediksi financial distress merupakan salah satu penyebab kebangkrutan perusahaan. Financial distress memiliki tanda-tanda diantaranya yaitu ketika perusahaan tidak lagi dapat memenuhi jadwal pembayarannya, produksi yang terus menurun dan sering mengalami keterlambatan pengiriman barang. Adapun pentingnya untuk memprediksi financial distress ini lebih dini adalah untuk dapat memperbaiki kondisi sebelum sampai pada tahap krisis. Rasio keuangan yang digunakan dalam penelitian ini sebagai acuan untuk memprediksi financial distress adalah profitability dan leverage. Menurut Platt dan Platt (2002) financial distress dapat diukur berdasarkan tiga kondisi yaitu saat mengalami laba operasi yang negatif selama beberapa tahun, melakukan penghentian terhadap pembayaran dividen, dan mengadakan restrukturisasi atau PHK, menurut Horne dan Wachowicz (2009), interest coverage ratio (ICR) merupakan salah satu rasio keuangan yang dapat digunakan untuk mengukur kemampuan perusahaan untuk memenuhi pembayaran bunganya, sehingga dapat menghindari kebangkrutan. Sedangkan menurut Elloumi dan Guoyie (2001:6) mendefinisikan financial distress sebagai perusahaan yang memiliki earning per share (EPS) yang negatif, sehingga tidak bisa memberikan kewajiban jangka pendeknya berupa pembagian deviden. Adapun beberapa perusahaan yang memiliki EPS yang negatif dalam periode 2011-2015 berdasarkan data annual yang didapat pada IDX.co.id adalah sebagai berikut :

Tabel 1.1

Daftar Perusahaan Yang Memiliki Earning Per Share (EPS) Negatif

\begin{tabular}{|c|c|c|c|c|c|c|c|}
\hline NO & KODE & EMITEN & 2011 & 2012 & 2013 & 2014 & 2015 \\
\hline 1 & IKAI & PT. Inti Keramik Alamasri Industri Tbk & -64 & -50 & -54 & -34 & -139 \\
\hline 2 & MLIA & PT. Mulia Industrindo Tbk & -29 & -23 & -359 & 97 & -122.23 \\
\hline 3 & BAJA & PT. Saranacentral Bajatama Tbk & 21 & 24,34 & $-42,85$ & 7,84 & $-5,19$ \\
\hline 4 & GDST & PT. Gunawan Dianjaya Steel Tbk & 12 & 6 & 11 & $-1,70$ & $-6,74$ \\
\hline 5 & JKSW & PT. Jakarta Kyoei Steel Works Tbk & $-20,40$ & $-115,37$ & $-55,46$ & $-64,52$ & $-154,62$ \\
\hline 6 & KRAS & PT. Krakatau Steel (Persero) Tbk & 65 & $-11,76$ & $-10,96$ & $-118,01$ & $-280,75$ \\
\hline 7 & JPRS & PT. Jaya Pari Steel Tbk & 50 & 13 & 20 & -9 & -29 \\
\hline 8 & BRPT & PT Barito Pacific Tbk & $-18,14$ & $-127,4$ & $-48,71$ & $-12,42$ & $-13,83$ \\
\hline 9 & AKKU & PT. Alam Karya Unggul Tbk & $-38,67$ & $-8,81$ & $-6,34$ & $-25,77$ & $-32,23$ \\
\hline 10 & FPNI & PT. Lotte Chemical Titan Tbk & $-20,86$ & $-29,4$ & $-13,39$ & $-14,90$ & $-6,91$ \\
\hline 11 & SIAP & PT. Sekawan Intipratama Tbk & 3,4 & 3,6 & $-6,25$ & $-3,26$ & $-1,07$ \\
\hline 12 & SIMA & PT. Siwani Makmur Tbk & $-345,44$ & $-56,58$ & $-15,47$ & 3,11 & $-3,35$ \\
\hline 13 & YPAS & PT. Yanaprima Hastapersada Tbk & 25 & 25 & 9 & -13 & -15 \\
\hline 14 & MAIN & PT. Malindo Feed Mill Tbk & 121 & 179 & 142 & -48 & -34 \\
\hline 15 & TIRT & PT. Tirta Mahakam Resources Tbk & 4 & -32 & -136 & -23 & $-0,86$ \\
\hline 16 & KBRI & PT. Kertas Basuki Rachmat Indonesia Tbk & $-2,38$ & 4,21 & $-2,10$ & $-1,86$ & $-17,93$ \\
\hline 17 & IMAS & PT. Indomobil Sukses Internasional Tbk & 347,27 & 289,93 & 192,55 & $-43,36$ & $-16,54$ \\
\hline 18 & LPIN & PT. Multi Prima Sejahtera Tbk & 533 & 781 & 403 & -194 & -831 \\
\hline 19 & ARGO & PT. argo pantes tbk & -323 & -355 & 244 & $-1117,98$ & $-414,9$ \\
\hline 20 & CNTX & PT. Century Textile Industry Tbk & 3355,9 & 3528 & $-121,78$ & 372,66 & $-132,4$ \\
\hline 21 & ESTI & PT. Evershine Tex Tbk & 1,62 & $-4,9$ & $-9,74$ & $-2,48$ & $-1,38$ \\
\hline 22 & HDTX & PT. Panasia Indo Resources Tbk & 12,61 & 3,92 & $-140,47$ & $-62,35$ & $-0,12$ \\
\hline 23 & MYTX & PT. Apac Citra Centertex Tbk & -32 & -36 & -15 & -49 & -81 \\
\hline 24 & POLY & PT. Asia Pacific Fibers Tbk & 257 & -98 & $-121,78$ & $-372,66$ & $-138,3$ \\
\hline 25 & SSTM & PT. Sunsan Textile Manufacture Tbk & $-20,58$ & $-12,08$ & $-11,30$ & $-10,97$ & -9 \\
\hline 26 & TFCO & PT. Tifico Fiber Indonesia Tbk & 63,49 & 19,6 & $-24,36$ & $-12,42$ & $-4,15$ \\
\hline 27 & ADMG & PT. Polychem Indonesia Tbk & Rp.74 & 21,56 & 3,65 & $-75,77$ & $-85,75$ \\
\hline 28 & PSDN & PT. Prashida Aneka Niaga Tbk & 9 & 9,78 & 5,48 & $-21,27$ & $-32,66$ \\
\hline 29 & RMBA & PT. Bentoel Internasional Investama Tbk & 42,26 & $-44,66$ & $-143,93$ & $-314,74$ & $-223,32$ \\
\hline 30 & SCPI & PT. Schering Plough Indonesia Tbk & $-7,06$ & $-3,43$ & $-3,38$ & $-17,35$ & $-38,70$ \\
\hline
\end{tabular}

(Sumber: Data dari IDX.co.id yang telah diolah) 


\section{LITERATUR}

\section{Teori}

Menurut G.R Terry yang dikutip dalam Hasibuan (2009:2) mengemukakan bahwa manajemen adalah : "Manajemen adalah suatu proses yang khas yang terdiri dari tindakantindakan perencanaan, pengarahan,dan pengendalian yang dilakukan untuk menentukan serta mencapai sasaran-sasaran yang telah ditentukan melalui pemanfaatan sumber daya manusia dan sumber-sumber lainnya”.

Menurut Sutrisno (2012:3) mengemukakan bahwa Manajemen Keuangan adalah:

“ Manajemen keuangan merupakan semua aktifitas perusahaan yang berhubungan dengan usaha-usaha mendapatkan dana perusahaan dengan biaya yang murah serta usaha untuk menggunakan dan mengalokasikan dana tersebut secara efisien”.

Menurut Munawir yang dikutip dari Fahmi (2012:2) mengemukakan bahwa laporan keuangan adalah :"Laporan Keuangan merupakan alat yang sangat penting untuk memperoleh informasi sehubungan dengan posisi keuangan dan hasil-hasil yang telah dicapai perusahaan yang bersangkutan”.

Fahmi (2012:55) mengemukakan bahwa pasar modal adalah : "Pasar Modal merupakan tempat dimana berbagai pihak khususnya perusahaan yang menjual saham (stock) dan obligasi (bond) dengan tujuan hasil penjualan tersebut nantinya akan digunakan nantinya sebagai tambahan dana atau memperkuat dana perusahaan”.

Menurut keputusan menteri BUMN Nomor Kep-117/M-MBU/2002 mengemukakan good corporate governance adalah :” good corporate governance merupakan suatu proses dan struktur yang digunakan oleh organisasi BUMN untuk meningkatkan keberhasilan usaha dan akuntabilitas perusahaan guna mewujudkan nilai pemegang saham dalam jangka panjang dengan memperhatikan kepentingan stakeholder, berdasarkan peraturan prundangan dan nilai-nilai etik”.

Institutional ownership (kepemilikan institusional) menurut Widarjo (2010:25) mengemukakan bahwa kepemilikan institusional adalah : "Kepemilikan institusional adalah kondisi dimana institusi memiliki saham dalam suatu perusahaan. Institusi tersebut dapat berupa pemerintah, institusi swasta maupun asing”.

Menurut Masdupi (2005:200), Kepemilikan Institusional dapat dirumuskan, sebagai

berikut :

$$
\text { KINS }=\frac{\text { Jumlah Saham Institusi }}{\text { Jumlah Saham Beredar }} \times 100 \%
$$

Profitabilitas menurut Agus Sartono dalam Irham Fahmi (2013:135) mengemukakan bahwa profitabilitas adalah : "Profitabilitas adalah rasio yang mengukur efektivitas manajemen secara keseluruhan yang ditujukan oleh besar kecilnya tingkat keuntungan yang diperoleh dalam hubungannya dengan penjualan maupun investasi”.

$$
\text { Return On Asset }=\frac{\text { Keuntungan sesudah bunga dan pajak }}{\text { Jumlah Aktiva }}
$$

Agus Harjito dan Martono (2011:315) mengemukakan bahwa leverage adalah : "Leverage dalam pengertian bisnis mengacu pada penggunaan asset dan sumber dan sumber dana (Sources Of Funds) oleh perusahaan dimana dalam penggunaan asset atau dana tersebut perusahaan harus mengeluarkan biaya tetap atau beban tetap. 


$$
\text { Debt to Total Asset Ratio }=\frac{\text { Total Hutang }}{\text { Total Aktiva }}
$$

Financial distress menurut Plat dan Plat dalam Fahmi (2013:158) mengemukakan bahwa financial distress adalah : "Financial distress adalah suatu tahap penurunan kondisi keuangan yang terjadi sebelum terjadinya kebangkrutan ataupun likuidasi. Financial distress dimulai dengan ketidakmampuan memenuhi kewajiban kewajibannya, terutama kewajiban yang bersifat jangka pendek termasuk kewajiban likuiditas, dan juga termasuk kewajiban dalam kategori solvabilitas”. Dikemukakan oleh Elloumi dan Gueyie (2001:6) yang mengemukakan bahwa financial distress sebagai suatu kondisi dimana suatu perusahaan memiliki earning per share (EPS) yang negatif dalam jangka waktu yang berturut-turut. Sehingga dengan acuan ini peneliti menetapkan bahwa Earning Per Share (EPS) akan digunakan sebagai indikator financial distress pada penelitian ini.

Earning Per Share (EPS) menurut Darmadji dan Fakhrudin (2015:54), mengemukakam bahwa : "Earning Per Share (EPS) adalah rasio yang menunjukan bagian laba untuk setiap saham. EPS menggambarkan profitabilitas perusahaan yang tergambar pada setiap lembar sahamnya”.

$$
\text { Earning Per Share (EPS) }=\frac{\text { Laba Bersih }}{\text { Jumlah Saham Yang Beredar }}
$$

\section{METODE PENELITIAN}

Metode penelitian yang digunakan peneliti dalam penelitian ini adalah jenis penelitian melalui pendekatan kuantitatif Asosiatif yang berhubungan secara kausal dengan tingkat signifikansi atau tingkat kesalahan sebesar 5\%. pengumpulan data yang digunakan dalam penelitian ini adalah melalui cara studi dokumenter Bursa Efek Indonesia (IDX) yang sumber datanya berupa data sekunder dimana peneliti memperoleh data melalui media perantara yang disajikan oleh Idx.co.id dan SahamOk.com sebagai penyusun laporan ketercatatan emiten. Untuk kepentingan analisis maka digunakan pooling data selama 5 tahun mulai tahun 2011-2015 dari perusahaan-perusahaan sampel. teknik pengambilan sampel acak stratified random sampling.

Tabel 1.2

Stratified Data Sampel Sub-Sektor manufaktur

Listed Bursa Efek Indonesia (IDX) Tahun 2011-2015

\begin{tabular}{llllll} 
NO & KODE & \multicolumn{1}{c}{ EMITEN } & NO & KODE & \multicolumn{1}{c}{ EMITEN } \\
\hline $\mathbf{1}$ & IKAI & PT. Inti Keramik Alamasri Industri Tbk & 16 & KBRI & PT. Kertas Basuki Rachmat Indonesia Tbk \\
\hline $\mathbf{2}$ & MLIA & PT. Mulia Industrindo Tbk & 17 & IMAS & PT. Indomobil Sukses Internasional Tbk \\
\hline $\mathbf{3}$ & BAJA & PT. Saranacentral Bajatama Tbk & 18 & LPIN & PT. Multi Prima Sejahtera Tbk \\
\hline $\mathbf{4}$ & GDST & PT. Gunawan Dianjaya Steel Tbk & 19 & ARGO & PT. argo pantes tbk \\
\hline $\mathbf{5}$ & JKSW & PT. Jakarta Kyoei Steel Works Tbk & 20 & CNTX & PT. Century Textile Industry Tbk \\
\hline $\mathbf{6}$ & KRAS & PT. Krakatau Steel (Persero) Tbk & 21 & ESTI & PT. Evershine Tex Tbk \\
\hline $\mathbf{7}$ & JPRS & PT. Jaya Pari Steel Tbk & 22 & HDTX & PT. Panasia Indo Resources Tbk \\
\hline $\mathbf{8}$ & BRPT & PT Barito Pacific Tbk & 23 & MYTX & PT. Apac Citra Centertex Tbk \\
\hline $\mathbf{9}$ & AKKU & PT. Alam Karya Unggul Tbk & 24 & POLY & PT. Asia Pacific Fibers Tbk \\
\hline $\mathbf{1 0}$ & FPNI & PT. Lotte Chemical Titan Tbk & 25 & SSTM & PT. Sunsan Textile Manufacture Tbk \\
\hline $\mathbf{1 1}$ & SIAP & PT. Sekawan Intipratama Tbk & 26 & TFCO & PT. Tifico Fiber Indonesia Tbk \\
\hline $\mathbf{1 2}$ & SIMA & PT. Siwani Makmur Tbk & 27 & ADMG & PT. Polychem Indonesia Tbk \\
\hline $\mathbf{1 4}$ & YPAS & PT. Yanaprima Hastapersada Tbk & 28 & PSDN & PT. Prashida Aneka Niaga Tbk \\
\hline $\mathbf{1 5}$ & TIRT & PT. Malindo Feed Mill Tbk & 29 & RMBA & PT. Bentoel Internasional Investama Tbk \\
\hline (Sumber $:$ Data hasil Olahan Stratified Sampling) & 30 & SCPI & PT. Schering Plough Indonesia Tbk \\
\hline
\end{tabular}

Dalam penelitian ini digunakan regresi data panel. Data panel adalah data yang memiliki jumlah crossection dan jumlah time series. 


\section{Langkah-langkah Pengujian Data Panel}

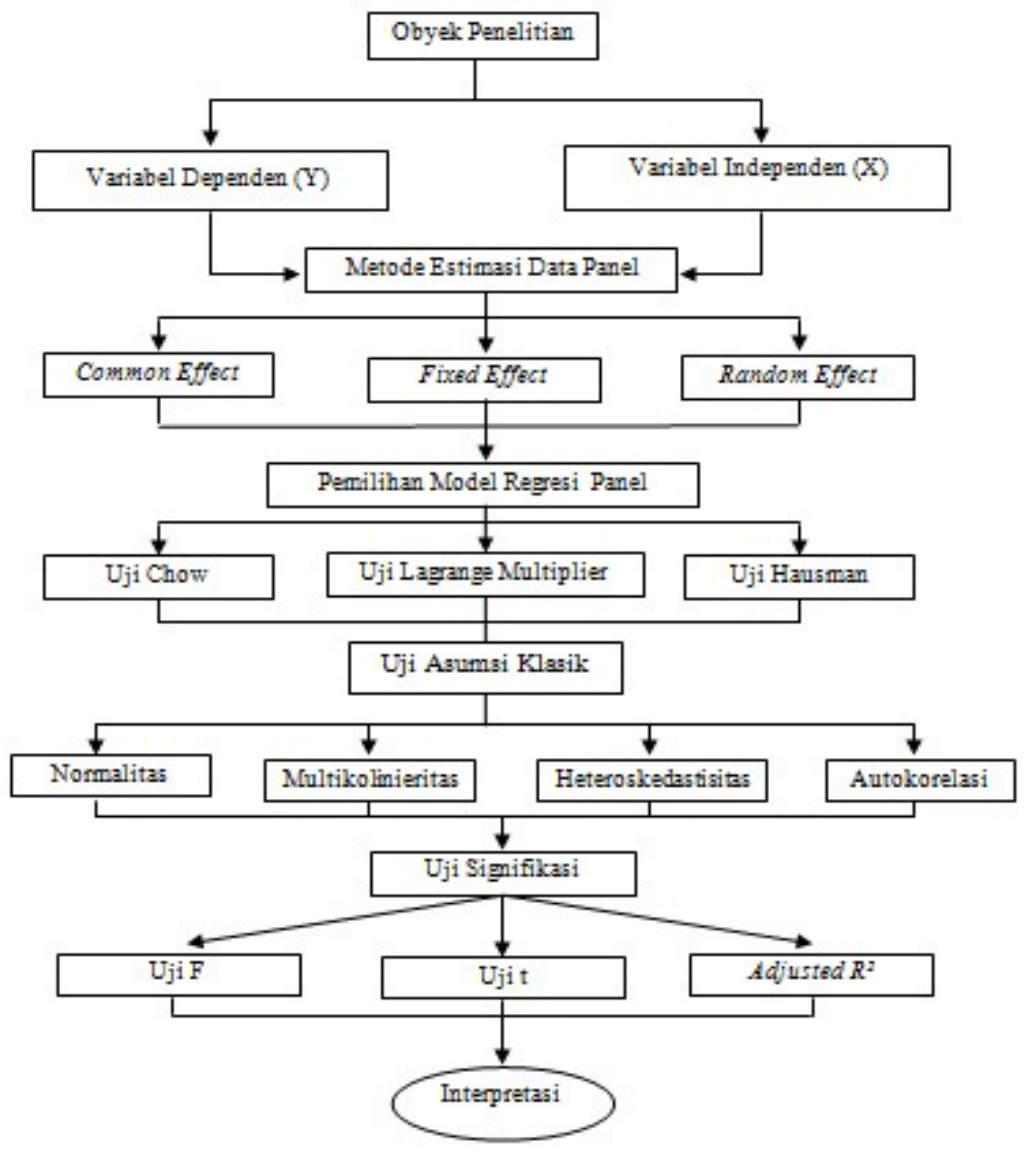

Gambar 3.2 : Skema Pengujian Data Panel

\section{Pemilihan Model Estimasi}

Uji Chow (F Statistik) Pengujian spesifikasi bertujuan untuk menentukan model analisis data panel yang akan digunakan.

$$
C H O W=\frac{R R S S-U R S S / N-1}{U R S S / N T-N-K}
$$

Uji Haussman pengujian ini bertujuan untuk mengetahui model yang sebaiknya dipakai, yaitu Fixed Effect Model (FEM) atau Random Effect Model (REM).

$$
W=X^{2}[K-1]=[b-\hat{\beta}]^{\hat{\psi}^{-1}}[b-\hat{\beta}]
$$

Uji Lagrange Multiplier (LM) untuk mengetahui apakah model Random Effect lebih baik daripada metode Common Effect (OLS)

Koefisien Korelasi dengan menggunakan metode analisis korelasi Pearson Product Moment dengan menggunakan rumus sebagai berikut :

$$
r=\frac{n \sum X Y-\sum X \sum Y}{\sqrt{\left(n \sum X^{2}-\left(\sum X\right)^{2}\right) \times\left(n \sum Y^{2}-\left(\sum Y\right)^{2}\right)}}
$$


Tabel 1.3

Kriteria Penilaian Korelasi

\begin{tabular}{cc}
\hline Interval Koefisien & Tingkat Pengaruh \\
\hline $0.00-0.199$ & Sangat Rendah \\
\hline $0.20-0.399$ & Rendah \\
\hline $0.40-0.599$ & Sedang \\
\hline $0.60-0.799$ & Kuat \\
\hline $0.80-1.000$ & Sangat Kuat
\end{tabular}

(Sugiyono, 2014:216)

Dalam melakukan estimasi persamaan linear dengan menggunakan metode ordinary least square OLS maka asumsi BLUE ( Best Linear Unbiased Estimator ) harus terpenuhi, diantaranya, adalah :

1. Nilai harapan dari rata-rata kesalahan adalah nol.

2. Varians tetap (Homokedastisitas)

3. Tidak berpengaruh antara variabel bebas dengan error term

4. Tidak ada korelasi serial antara error

5. Tidak ada multikolinearitas

Table 1.4

Table Syarat Uji Pelanggaran Asumsi

\begin{tabular}{|c|c|c|c|c|}
\hline $\begin{array}{c}\text { Uji Asumsi } \\
\text { Klasik }\end{array}$ & $\begin{array}{c}\text { Uji } \\
\text { Heteroskedastisitas }\end{array}$ & $\begin{array}{c}\text { Uji } \\
\text { Autokorelasi }\end{array}$ & $\begin{array}{c}\text { Uji } \\
\text { Multikolinieritas }\end{array}$ & $\begin{array}{c}\text { Uji } \\
\text { Normalitas }\end{array}$ \\
\hline Common effect & $\sqrt{ }$ & & $\sqrt{ }$ & $\sqrt{ }$ \\
\hline Fixed effect & $\sqrt{ }$ & $\sqrt{ }$ & $\sqrt{ }$ & $\sqrt{ }$ \\
\hline Random effect & $\sqrt{ }$ & & $\sqrt{ }$ & \\
\hline
\end{tabular}

(Sumber : Gujarati Dan Porter 2009)

\section{Hipotesis}

$\mathrm{H}_{0}$ : Institutional Ownership, Profitability dan Leverage secara parsial dan simultan berpengaruh terhadap Financial Distress

Uji T (T-Test) melakukan pengujian terhadap koefisien regresi secara parsial, nilai t-hitung dicari dengan rumus :

$$
\mathrm{T}_{\text {hitung }}: \frac{\mathrm{r} \sqrt{\mathrm{n}-2}}{\sqrt{1-\mathrm{r}^{2}}}
$$

Kriteria , jika berdasarkan perbandingan t-hitung dengan t-tabel.

$\mathrm{T}_{\text {hitung }}>\mathrm{T}_{\text {tabel }}(\alpha, \mathrm{n}-\mathrm{k}-\mathrm{l})$, maka $\mathrm{H}_{0}$ ditolak.

$\mathrm{T}_{\text {hitung }}<\mathrm{T}_{\text {tabel }}(\alpha, \mathrm{n}-\mathrm{k}-\mathrm{l})$, maka $\mathrm{H}_{0}$ diterima.

Uji F (Test-Statistic) Uji ini digunakan untuk menguji keberartian pengaruh dari seluruh variabel independen secara bersama-sama terhadap variabel dependen, nilai f-hitung dapat dicari dengan rumus :

$$
\mathrm{F}_{\text {hitung }}: \frac{\mathrm{R}^{2} /(\mathrm{k}-1)}{\left(1-\mathrm{R}^{2}\right) /(\mathrm{n}-\mathrm{k}-1)}
$$

Kriteria , jika berdasarkan perbandingan f-hitung dan f-tabel.

$\mathrm{F}_{\text {hitung }}>\mathrm{F}_{\text {tabel }}(\mathrm{a}, \mathrm{k}-\mathrm{l}, \mathrm{n}-\mathrm{l})$, maka $\mathrm{H}_{0}$ ditolak. 


$$
\mathrm{F}_{\text {hitung }} \leq \mathrm{F}_{\text {tabel }}(\mathrm{a}, \mathrm{k}-\mathrm{l}, \mathrm{n}-\mathrm{l}) \text {, maka } \mathrm{H}_{0} \text { diterima }
$$

Koefisiensi Regresi Linier Berganda bermaksud meramalkan bagaimana keadaan (naik turunnya) variabel dependen (kriterium), bila dua atau lebih variabel independen sebagai faktor prediator dimanipulasi (dinaik turunkan nilainya). Pengujian hipotesis di atas bertujuan untuk menguji seberapa besar pengaruh variabel-variabel independen atau variabel bebas terhadap variabel dependen atau variabel terikat, digunakan analisis regresi berganda dengan persamaan kuadrat terkecil dengan model dasar sebagai berikut :

$$
Y=\beta_{0 i}+\beta X_{1 i}+\beta X_{2 i}+\beta X_{3 i}+\varepsilon_{i}
$$

Koefisien Determinasi merupakan ukuran untuk mengetahui kesesuaian atau ketepatan antara nilai dugaan atau garis regresi dengan data sampel. Apabila nilai koefisien korelasi sudah diketahui, maka untuk mendapatkan koefisien determinasi dapat diperoleh dengan mengkuadratkannya. Besarnya koefisien determinasi dapat dihitung dengan menggunakan rumus sebagai berikut :

$$
\mathrm{KD}=\mathrm{r} 2 \times 100 \%
$$

\section{HASIL DAN PEMBAHASAN \\ Pemilihan Model Estimasi \\ Uji Chow (F Statistik)}

Tabel Hasil Pengujian Chow Test

Dependent Variable: EPS_Y

Method: Panel Least Squares

Date: 01/29/18 Time: 17:27

Sample: 20112015

Periods included: 5

\begin{tabular}{|c|c|c|c|c|}
\hline Variable & Coefficient & Std. Error & t-Statistic & Prob. \\
\hline KINS_X1 & 2.953022 & 47.33628 & 0.062384 & 0.9503 \\
\hline ROA_X2 & 754.1984 & 339.1140 & 2.224026 & 0.0277 \\
\hline DTA_X3 & -21.70652 & 50.82729 & -0.427064 & 0.6700 \\
\hline $\mathrm{C}$ & 54.85438 & 66.92709 & 0.819614 & 0.4138 \\
\hline R-squared & 0.038558 & \multicolumn{2}{|c|}{ Mean dependent var } & 16.78667 \\
\hline Adjusted R-squared & 0.018802 & \multicolumn{2}{|c|}{ S.D. dependent var } & 438.7115 \\
\hline S.E. of regression & 434.5676 & \multicolumn{2}{|c|}{ Akaike info criterion } & 15.01288 \\
\hline Sum squared resid & 27571956 & \multicolumn{2}{|c|}{ Schwarz criterion } & 15.09317 \\
\hline Log likelihood & -1121.966 & \multicolumn{2}{|c|}{ Hannan-Quinn criter. } & 15.04550 \\
\hline F-statistic & 1.951723 & \multicolumn{2}{|c|}{ Durbin-Watson stat } & 0.823809 \\
\hline Prob(F-statistic) & 0.123870 & & & \\
\hline Variable & Coefficient & Std. Error & t-Statistic & Prob. \\
\hline KINS_X1 & -1.830481 & 47.12837 & -0.038840 & 0.9691 \\
\hline ROA_X2 & 540.4361 & 371.4924 & 1.454771 & 0.1484 \\
\hline
\end{tabular}

Cross-sections included: 30

Total panel (balanced) observations: 150 


\begin{tabular}{lllll} 
DTA_X3 & -145.4732 & 152.1136 & -0.956346 & 0.3409 \\
C & 149.0548 & 126.5571 & 1.177768 & 0.2413 \\
\hline
\end{tabular}

Effects Specification

Cross-section fixed (dummy variables)

\begin{tabular}{llll}
\hline \hline R-squared & 0.398991 & Mean dependent var & 16.78667 \\
Adjusted R-squared & 0.234612 & S.D. dependent var & 438.7115 \\
S.E. of regression & 383.8131 & Akaike info criterion & 14.92973 \\
Sum squared resid & 17235560 & Schwarz criterion & 15.59207 \\
Log likelihood & -1086.730 & Hannan-Quinn criter. & 15.19881 \\
F-statistic & 2.427268 & Durbin-Watson stat & 1.324396 \\
Prob(F-statistic) & 0.000307 & & \\
\hline \hline
\end{tabular}

\section{F-Hitung}

$\begin{aligned} \mathrm{CHOW} & =\frac{\mathrm{RRSS}-\mathrm{URSS} / \mathrm{N}-1}{\mathrm{URSS} / \mathrm{NT}-\mathrm{N}-\mathrm{K}} \\ \mathrm{CHOW} & =\frac{27571956-17235560 / 30-1}{17235560 / 150-30-3}\end{aligned}$

CHOW $=2.339$

\author{
Result \\ $F_{2.339}<F_{2.670}$
}

Common Effect Model

\section{F-Tabel}

$\mathrm{df} 1=3, \mathrm{df}=150-3-1=2.670$

\section{Uji Hausman}

\section{Tabel Hasil Pengujian Hausman}

Correlated Random Effects - Hausman Test

Equation: Untitled

Test cross-section random effects

\begin{tabular}{llll}
\hline Test Summary & Chi-Sq. Statistic Chi-Sq. d.f. & Prob. \\
\hline Cross-section random & 0.855841 & 3 & 0.8361 \\
\hline
\end{tabular}

Hasil dari penghitungan statistik Hausman adalah sebesar 0,855841, sedangkan nilai kritis Chi-Squares dengan df sebesar 3 pada $\alpha=0,05$ adalah sebesar 7,8147 yang berarti bahwa nilai nilai statistik Hausman lebih kecil dari nilai kritis Chi-Squares. Dengan demikian maka dapat disimpulkan bahwa $\mathrm{H} 1$ diterima dan $\mathrm{H} 0$ ditolak yang berarti model yang lebih tepat digunakan dalam penelitian ini adalah model Random Effect.

$$
\begin{gathered}
\text { Result } \\
H_{0.8558<} C_{7.8147}
\end{gathered}
$$

\section{Random Effect Model}

Uji Lagrange Multiplier (LM) 


\section{Tabel Hasil Pengujian Lagrange Multiplier (LM)}

Lagrange Multiplier Tests for Random Effects

Null hypotheses: No effects

Alternative hypotheses: Two-sided (Breusch-Pagan) and one-sided

(all others) alternatives

\begin{tabular}{llll}
\hline & \multicolumn{2}{c}{ Cross-section } & \multicolumn{1}{c}{ Test Hypothesis } \\
& 13.64313 & 0.283464 & \multicolumn{1}{c}{ Both } \\
\hline Breusch-Pagan & $(0.0002)$ & $(0.5944)$ & $(0.92659$ \\
& 3.693660 & 0.532413 & 2.988285 \\
Honda & $(0.0001)$ & $(0.2972)$ & $(0.0014)$ \\
& 3.693660 & 0.532413 & 1.785071 \\
King-Wu & $(0.0001)$ & $(0.2972)$ & $(0.0371)$ \\
Standardized Honda & 4.039718 & 0.921237 & -0.914702 \\
Standardized King-Wu & $(0.0000)$ & $(0.1785)$ & $(0.8198)$ \\
& 4.039718 & 0.921237 & -0.971118 \\
Gourieroux, et al.* & $(0.0000)$ & $(0.1785)$ & $(0.8343)$ \\
& -- & - & 13.92659 \\
& & & $(0.0003)$ \\
\hline
\end{tabular}

Dari hasil output diatas dapat dilihat bahwa nilai probabilitas Breusch-Pagan sebesar $0,0002<0,05$ yang berarti bahwa H0 ditolak. Dengan demikian, model yang lebih baik diantara common effect dan random effect adalah model random effect.

Tabel Pemilihan Akhir Model Estimasi

\begin{tabular}{cccc}
\hline MODEL & Uji Chow & Uji Hausman & Uji Lagrange \\
\hline Common effect & $\sqrt{ }$ & & \\
\hline Fixed effect & & & \\
\hline Random effect & & $\sqrt{ }$ & $\sqrt{ }$ \\
\hline
\end{tabular}

Dalam tiga pengujian di atas menunjukan bahwa lebih tepat digunakan model random effect.

\section{Asumsi Klasik}

Tabel Uji Asumsi Klasik Model Estimasi Random Effect

\begin{tabular}{|l|l|}
\hline \multicolumn{1}{|c|}{ Pengujian } & \multicolumn{1}{|c|}{ Hasil } \\
\hline \multirow{3}{*}{ Heteroskedastisitas } & $\begin{array}{l}\text { Penyebaran titik-titik data tidak membentuk } \\
\text { pola bergelombang melebar kemudian }\end{array}$ \\
& menyempit dan melebar lagi serta \\
penyebaran titik-titik data tidak berpola \\
maka dengan demikian dapat disimpulkan \\
bahwa tidak terjadi masalah \\
heterokedastistas (varians bersifat \\
homogen)
\end{tabular}




\begin{tabular}{|l|l|}
\hline Pengujian & \multicolumn{1}{c|}{ Hasil } \\
\hline & $\begin{array}{l}\text { tegas bahwa tidak terdapat masalah pada } \\
\text { multikoleniaritas }\end{array}$ \\
\hline
\end{tabular}

\section{Analisis}

Dependent Variable: EPS_Y

Table Analisis Model Random Effect

Method: Panel EGLS (Cross-section random effects)

Date: 01/30/18 Time: 14:39

Sample: 20112015

Periods included: 5

Cross-sections included: 30

Total panel (balanced) observations: 150

Swamy and Arora estimator of component variances

\begin{tabular}{crrrr}
\hline \hline Variable & Coefficient & Std. Error & t-Statistic & Prob. \\
\hline \hline KINS_X1 & 0.085397 & 44.88236 & 0.001903 & 0.9985 \\
ROA_X2 & 669.6959 & 335.2464 & 1.997623 & 0.0476 \\
DTA_X3 & -38.32041 & 68.11094 & -0.562618 & 0.5746 \\
C & 67.63115 & 82.62309 & 0.818550 & 0.4144 \\
\hline \hline
\end{tabular}

Effects Specification

\begin{tabular}{lcc} 
& S.D. & Rho \\
\hline \hline Cross-section random & 220.5938 & 0.2483 \\
Idiosyncratic random & 383.8131 & 0.7517 \\
\hline \hline
\end{tabular}

Weighted Statistics

\begin{tabular}{lllr}
\hline \hline R-squared & 0.033775 & Mean dependent var & 10.30876 \\
Adjusted R-squared & 0.013921 & S.D. dependent var & 383.6641 \\
S.E. of regression & 380.9843 & Sum squared resid & 21191760 \\
F-statistic & 1.701155 & Durbin-Watson stat & 1.070405 \\
Prob(F-statistic) & 0.169370 & & \\
\hline \hline
\end{tabular}

Unweighted Statistics

\begin{tabular}{lrlr}
\hline \hline R-squared & 0.037614 & Mean dependent var & 16.78667 \\
Sum squared resid & 27599018 & Durbin-Watson stat & 0.821905 \\
\hline
\end{tabular}

\section{Analisisis Koefisiensi Determinasi}

Analisis koefisien determinasi secara simultan digunakan untuk mengetahui persentase KINS, ROA dan DTA terhadap EPS. Dan berdasarkan tabel output model random effect di atas dapat diketahui bahwa nilai $R$-square sebesar 0,033775 artinya secara bersama-sama variabel KINS, ROA dan DTA mempunyai kontribusi menjelaskan EPS sebesar 3,37\%, sedangkan sisanya sebesar 96,3\% (100\%-3,37\%) dijelaskan oleh variabel lain yang tidak diteliti atau tidak dimasukkan dalam model penelitian ini. 


\section{Analisis Koefisiensi Korelasi Berganda}

Dari output tabel model random effect di atas didapat koefisien determinasi R2 $(R$ Square) antara KINS, ROA dan DTA dengan Financial Distres adalah sebesar 0,033775. Maka nilai $\mathrm{R}$ adalah $\sqrt{ } 0,033775=0,18378$. Angka $\mathbf{0 , 1 8 3 7 8}$ menunjukan bahwa terjadi hubungan yang Sangat Rendah antara ketiga variabel independen dengan variabel dependen.

\section{Analisis Uji Hipotesis}

Uji- F

Berdasarkan hasil uji statistik F tabel output model random effect di atas, output regresi menunjukkan nilai F Hitung 0,169370 <0,267 ( $\alpha=n-k-1(5 \%)=150-3-1$ Ho diterima), sehingga dapat disimpulkan bahwa secara bersama-sama variabel KINS, ROA dan DTA tidak berpengaruh secara signifikan terhadap variabel EPS.

Uji-T

Berdasarkan hasil pada tabel diatas uji regresi parsial (Uji t) menunjukkan bahwa nilai koefisien regresi variabel KINS sebesar 0,085397 dengan t sebesar 0,001903 < 1,65529 (Ho diterima) dan signifikansi 0,9985 > 0,05, hal ini menunjukkan tidak terdapat pengaruh KINS terhadap EPS secara positif dan tidak signifikan.

Berdasarkan hasil pada tabel diatas nilai koefsien regresi variabel ROA sebesar 669,6959 dengan t sebesar 1,997623 > 1,65529 (Ho ditolak) dan signifikansi sebesar 0,0476 $<0,05$, hal ini menunjukan bahwa ROA berpengaruh terhadap EPS secara positif dan walaupun signifikan.

Berdasarkan hasil pada tabel diatas, nilai koefsien regresi variabel DTA sebesar 38,32041 dengan t sebesar $-0,562628<1,65529$ (Ho diterima) dan signifikansi 0,5746 > 0,05 menunjukkan bahwa tidak terdapat pengaruh variabel DTA terhadap EPS adalah secara negatif dan tidak signifikan.

\section{Analisis Koefisiensi Regresi Berganda}

$$
\begin{aligned}
& y_{i t}=\alpha+\beta X_{l t}+\grave{u}_{\imath}+\varepsilon_{l t} \\
& E P S_{-} Y=\alpha+\beta_{1} K I N S_{-} X_{1}+\beta_{2} R O ̀ A_{-} X_{2}+\beta_{3} D T A_{-} X_{3} \\
& E P S_{Y}=67.6311+669.6958 X_{2}
\end{aligned}
$$

Nilai koefisien regresi X2 memiliki hubungan positif 669,6958 untuk variabel ROA yang artinya setiap kenaikan $1 \%$ ROA, maka financial distress akan mengalami kenaikan sebesar 669,6958 satuan.

\section{SIMPULAN}

Hasil penelitian yang telah dilakukan peneliti menunjukkan bahwa terdapat pengaruh yang positif tetapi tidak signifikan dari return on asset (ROA) terhadap kemungkinan terjadinya kondisi financial distress. Hal ini dibuktikan bahwa semakin besar nilai return on asset (ROA) suatu perusahaan maka akan menurunkan potensi kemungkinan terjadinya kondisi financial distress, Dari implikasi penelitian tersebut menunjukan bahwa sangat penting sekali agar perusahaan - perusahaan dapat tetap menjaga nilai return on asset (ROA) sehingga perusahaan akan dapat mengurangi resiko terjadinya kondisi financial distress.

\section{DAFTAR PUSTAKA}


Agus Sartono, 2010. Manajemen Keuangan Teori dan Aplikasi. Cetakan Keempat. BPFE, Yogyakarta.

Arikunto, Suharsimi, 2006. Prosedur Penelitian Suatu Pendekatan Praktik. Rineka Cipta, Jakarta.

Bambang, Riyanto, 2001. Dasar-dasar Pembelanjaan Perusahaan. BPFE, Yogyakarta.

David, Fred R, 2010. Manajemen Strategis Konsep, PT. Prenhallindo, Jakarta.

Elloumi Dan Gueyie, 2001. Financial distress and corporate governance; An empirical prediction of corporate distress, journal of money investment and banking, Vol:11 6-15.

Fahmi, Irham, 2012. Analisis Laporan Keuangan. Cetakan Kedua, Alfabeta Bandung.

Fahmi, irham, 2013. Pengantar Manajemen Keuangan Teori Dan Soal Jawaban. Cetakan Kedua, Alfabeta, Bandung.

George, Terry, 2006. Prinsip - Prinsip Management. Terjemahan Kencana Syafiie. PT. Bumi Aksara, Jakarta.

Gujarati, Damodar, 2013. Dasar-Dasar Ekonometrika. Edisi Kelima Salemba Empat, Jakarta.

Hadi, Nor, 2013. Pasar Modal. Graha Ilmu, Yogyakarta.

Hasibuan, Malayu S.P, 2009. Manajemen: Dasar, Pengertian Dan Masalah Edisi Revisi, Bumi Aksara, Jakarta.

Hanafi, Mamduh dan Halim, Abdul, 2012. Analisis Laporan Keuangan, Edisi Ketiga Cetakan Pertama, UPP sekolah tinggi ilmu manajemen, YKPN, Yogyakarta.

Hery, 2012. Analisis Laporan Keuangan, Bumi Aksara, Jakarta.

Horne, James C. Van dan John M. Waschowicz. Jr 2012 Prinsip-Prinsip Manajemen Keuangan. Edisi Ke 13 Buku 1, Salemba Empat, Jakarta.

Husein, Umar, 2005. Metode Penelitian untuk Skripsi dan Tesis Bisnis. PT. Raja Grafindo Persada, Jakarta.

Imanta, Dea., Satwiko, Rutji, 2011. Faktor-Faktor Yang Mempengaruhi Kepemilikan Managerial. Jurnal Bisnis dan Akuntansi, vol 13.

Kasmir, 2014. Bank Dan Lembaga Keuangan Lainnya, PT. Raja Grafindo, Cetakan Keempat Belas, Persada, Jakarta.

Latumaerisa, Julius R, 2011. Bank Dan Lembaga Keuangan Lain, Cetakan Pertama, Salemba Empat, Jakarta.

Lestari, Maharani Ika dan Toto Sugiharto, 2007. Kinerja Bank Devisa dan Bank Non Devisa dan Faktor-faktor yang mempengaruhinya. Proceeding PESAT, Volume Dua, Fakultas Ekonomi, Gunadarma.

Mardiyanto, Handoyo, 2009. Intisari Manajemen Keuangan. PT.Grasindo, Jakarta.

Masdupi, Erny, 2005. Analisis Dampak Struktur Kepemilikan Hutang Dalam Mengontrol Konflik Keagenan, Jurnal Ekonomi Dan Bisnis Indonesia Vol.20, No.1:6471.

Munawir, Drs, 2010. Analisis Laporan Keuangan, Liberty, Yogyakarta.

Nabela, Yoandika 2012 Pengaruh Kepemilikan Institusional, Kebijakan Deviden, Kepemilikan Saham Manajerial, Dan Kepemilikan Saham Institusional Terhadap Kebijakan Hutang Pada Perusahaan Property Dan Real Estate Di Bursa Efek Indonesia. Jurnal manajemen volume 01 No 01 September 2012.

PSAK, 2002. Standar Akuntansi Keuangan. Jilid Kedua. Ikatan Akuntan Indonesia. Erlangga, Jakarta.

PSAK, Revisi 2009. Standar Akuntansi Keuangan. Ikatan Akuntan Indonesia. Erlangga, Jakarta.

Safroni, Drs, 2012. Manajemen Dan Reformasi Pelayanan Publik, Bumi Aksara, Jakarta. 
Sugiyono, 2013. Metode Penelitian Manajemen. Cetakan Edisi Pertama, CV. Alfabeta, Bandung.

Sutedi, Adrian, 2013. Good Corporate Governance, Sinar Grafika, Jakarta.

Sutrisno,2012. Manajemen Keuangan : Teori, Konsep dan Aplikasi. Edisi Pertama, Cetakan Kedelapan. Ekonosia, Yogyakarta.

Sukrini, Dwi 2012, Kepemilikan Manajerial, Kepemilikan Institusional, Kebijakan Deviden Dan Kebijakan Hutang Analisis Terhadap Nilai Perusahaan, Accounting Analisys Journal 1 (2)(2012)

Tjiptono Darmadji Dan Hendi M Fakhrudin 2012 Pasar Modal Diindonesia. Edisi Ketiga, salemba empat, Jakarta.

Widarjo, Bandi 2010 Pengaruh Ownership Retention, Investasi Dari Proceeds Dan Reputasi Auditor Terhadap Nilai Perusahaan Dengan kepemilikan Manajerial Dan Institusional Sebagai Variabel Pemoderasi. Symposium Nasional Akuntansi

Web : Ke XIII, Purwokerto.

www.sahamOK.com

www.IDX.co.id 